\title{
PAR acclimation and UVBR-induced DNA damage in Antarctic marine microalgae
}

\author{
Anita G. J. Buma ${ }^{1, *}$, Simon W. Wright ${ }^{2}$, Rick van den Enden ${ }^{2}$, Willem H. van de Poll ${ }^{1}$ \\ Andrew T. Davidson ${ }^{2}$ \\ ${ }^{1}$ Department of Ocean Ecosystems, Centre for Ecological and Evolutionary Studies, University of Groningen, Kerklaan 30, \\ 9750 AA Haren, The Netherlands \\ ${ }^{2}$ Australian Antarctic Division and Antarctic Climate and Ecosystems Cooperative Research Centre, Channel Highway, \\ Kingston, Tasmania 7050, Australia
}

\begin{abstract}
Whether or not it is related to stratospheric ozone depletion, Antarctic microalgae experience ultraviolet-B radiation (UVBR) stress in situ, leading to decreased photosynthetic performance, DNA damage, and/or altered community composition. UVBR vulnerability is known to be species specific, but may also be affected by a range of environmental growth conditions, including the light history of the cells. This study investigates the influence of acclimation to photosynthetically active radiation (PAR) on the vulnerability to UVBR-induced DNA damage in Antarctic microalgae. Chaetoceros dichaeta, Pyramimonas gelidicola, Phaeocystis antarctica and Polarella glacialis were acclimated to 5 PAR levels, after which growth rate, pigment composition, malondialdehyde (MDA, a general indicator of oxidative stress) and UV-absorbing compounds were measured. Photoacclimated cultures were then exposed to a single UVBR treatment and the accumulation of UVBR-induced DNA damage was determined by the number of cyclobutane pyrimidine dimers (CPDs). Acclimation to increasing irradiance enhanced both the xanthophyll to chlorophyll a ratio and xanthophyll deepoxidation in all species. Increased cellular MDA levels were found at the highest irradiance in all species except $P$. gelidicola. Yet, growth rates were only reduced at the 2 lowest PAR levels. $P$. antarctica and P. glacialis showed a strong linear induction of UV-absorbing compounds at increasing PAR intensities, whereas $P$. gelidicola showed no induction of these compounds. The UVBR treatment induced CPDs in P. gelidicola only, and CPD levels were elevated at the highest PAR acclimation intensities. Thus, sensitivity to UVB-induced CPD accumulation was species specific, and, counterintuitively, acclimation to high PAR increased the sensitivity of $P$. gelidicola to UVBinduced DNA damage.
\end{abstract}

KEY WORDS: DNA damage - Xanthophyll pigments · Antarctic microalgae · Malondialdehyde · MDA $\cdot$ Photoacclimation $\cdot \mathrm{UVBR} \cdot \mathrm{CPDs}$

\section{INTRODUCTION}

Marine microalgae, including those inhabiting high latitude regions, experience ultraviolet-B radiation (UVBR: 280 to $315 \mathrm{~nm}$ wavelength) stress in situ. Natural UVBR levels are well known to structure Antarctic marine phytoplankton communities and affect overall productivity. There is a wealth of information on decreased photosynthetic rate (for reviews see Vernet 2000, Villafane et al. 2003) as well as on UVBRinduced DNA damage, expressed as cyclobutane pyrimidine dimers (CPDs) (for review see Buma et al. 2003). At the same time, species-specific differences in UVBR vulnerability (Karentz et al. 1991, Davidson et al. 1994) may, under prolonged (elevated) UVBR exposure, alter phytoplankton community composition, as demonstrated for a number of field locations including Antarctica (Bothwell et al. 1993, Villafane et al. 1995, Mostajir et al. 1999, Mousseau et al. 2000, Davidson \& Belbin 2002). In addition to the UVBR dose and dose rate, the extent to which microalgal communities suffer from in situ UVBR stress depends on the interaction 
with other environmental factors such as the rate and depth of vertical mixing (Helbling et al. 1994, Neale et al. 1998a, 2003) and nutrient concentrations (Behrenfeld et al. 1994, Lesser et al. 1994, Litchman et al. 2002, Shelley et al. 2002). In polar regions, UVBR levels are enhanced during spring time as a result of stratospheric ozone depletion, which may cause an integrated loss of carbon fixation in Antarctic waters between $<0.15$ and $12 \%$ (Smith et al. 1992, HolmHansen et al. 1993, Helbling et al. 1994).

The light history of cells can positively or negatively influence the UVBR tolerance. For example, acclimation to high irradiances of photosynthetically active radiation (PAR: 400 to $700 \mathrm{~nm}$ wavelength) or to ultraviolet-A radiation (UVAR: 315 to $400 \mathrm{~nm}$ wavelength) may induce production of mycosporine-like amino acids (MAAs), which protect the cells against incoming short wavelengths (Neale et al. 1998b, Banaszak 2003). Also, repair mechanisms, such as the enzymes that correct UVBR-induced DNA damage, may be more active when cells are acclimated to high in situ irradiances, as is found in higher plants (Takahashi et al. 2002, Waterworth et al. 2002). Conversely, high PAR and UVAR may cause oxidative stress, when excitation energy dissipates via pathways, leading to dangerous reactive intermediates such as singlet oxygen or other oxyradicals. In the latter case, radicals may damage proteins of the photosystem II (PSII) reaction centre and destroy membrane integrity, causing a decrease in photosynthetic performance or even viability loss (Poll et al. 2005). One recent study showed increased PAR- and UVR-induced viability loss, when cells were precultured at low irradiance levels, possibly related to increased pigmentation of the cells (Poll et al. 2005).

How photooxidative and antioxidative mechanisms affect UVBR sensitivity is largely unknown. Microalgae, as most organisms, develop or induce mechanisms that offer protection against excess solar irradiance (for review Banaszak 2003). Direct protection is provided by xanthophyll cycle activity (Demers et al. 1991, Olaizola et al. 1994), whereby excess excitation energy is dissipated as heat (Demers et al. 1991, Demming-Adams \& Adams 1992) in the cyclic de-epoxidation/epoxidation of diadinoxanthin/diatoxanthin (chromophytes including diatoms, prymnesiophytes and dinoflagellates) or of violaxanthin/zeaxanthin/ antheraxanthin (in chlorophytes and prasinophytes). The epoxidation state [EPS: epoxidated/(epoxidated + de-epoxidated pigments)] can, therefore, be considered an indicator of xanthophyll cycle activity under excess irradiance conditions. In addition, while acclimating to high irradiance, the pool of xanthophyll pigments may increase, whereas cellular light-harvesting pigments decrease (Demers et al. 1991).
Oxidative stress occurs when the rate of xanthophyll cycling or antioxidant enzyme action is exceeded by the oxiradical accumulation rate. One of the major consequences of oxidative stress is the oxidation of membrane lipids that may cause loss of cell permeability and, eventually, cell viability. During the process of membrane oxidation, harmful phospholipid residues may be formed, including malondialdehyde (MDA). MDA is considered a general indicator of oxidative stress in animal, human, as well as in micro- and macroalgal cells (Rijstenbil 2002, Bischof et al. 2003).

Considering the above, synergistic or antagonistic effects of PAR, UVAR and UVBR exposure are to be expected. Yet, the nature and extent to which this occurs in Antarctic microalgae needed to be further elucidated. One study with an Antarctic cyanobacterium showed UVBR vulnerability to be strongly dependent on the UVBR to UVAR ratio, with a lower ratio being more beneficial for the organisms (Quesada et al. 1995). This was suggested to be related to the induction of UVB protective stress proteins at higher UVAR levels. Here, we examined the effect of the PAR acclimation of 4 common Antarctic marine microalgae on their sensitivity to UVBR-induced DNA damage.

\section{MATERIALS AND METHODS}

Experimental set-up. Unialgal, non-axenic Antarctic microalgae were acclimated to PAR and exposed to UVBR in $500 \mathrm{ml}$ polysterene flasks (Techno Plastic Products TPP 90151) in GP5 medium (Loeblich \& Smith 1968, and modified after Loeblich 1975) based on filtersterilised natural seawater, in a temperature-controlled $\left(1.0 \pm 0.5^{\circ} \mathrm{C}\right)$ culture cabinet. The investigated species were: flagellates of the haptophyte Phaeocystis antarctica Karsten; the diatom Chaetoceros dichaeta Ehrenb.; the dinoflagellate Polarella glacialis Montresor, Procaccani \& Stoecker; and the prasinophyte Pyramimonas gelidicola McFadden, Moestrup \& Wetherbee (CS-139). All cultures were obtained from the Australian Antarctic Division culture collection. P. antarctica remained in the flagellated stage for the duration of the experimental period.

PAR levels were applied by varying the distance between the culture bottles and 20 watt (W) cool white fluorescent tubes (Osram, Germany, see Fig. 1 for spectral composition), thereby giving 5 irradiance levels between 18 and $220 \mu \mathrm{mol} \mathrm{m}{ }^{-2} \mathrm{~s}^{-1}$ in a $16 \mathrm{~h}$ light: $8 \mathrm{~h}$ dark cycle. PAR acclimation was achieved by keeping the cultures at their respective irradiances for a minimum of $2 \mathrm{wk}$, after which time the cultures were assumed to be acclimated. Cultures were regularly diluted with fresh medium to avoid nutrient depletion during the experiments. 


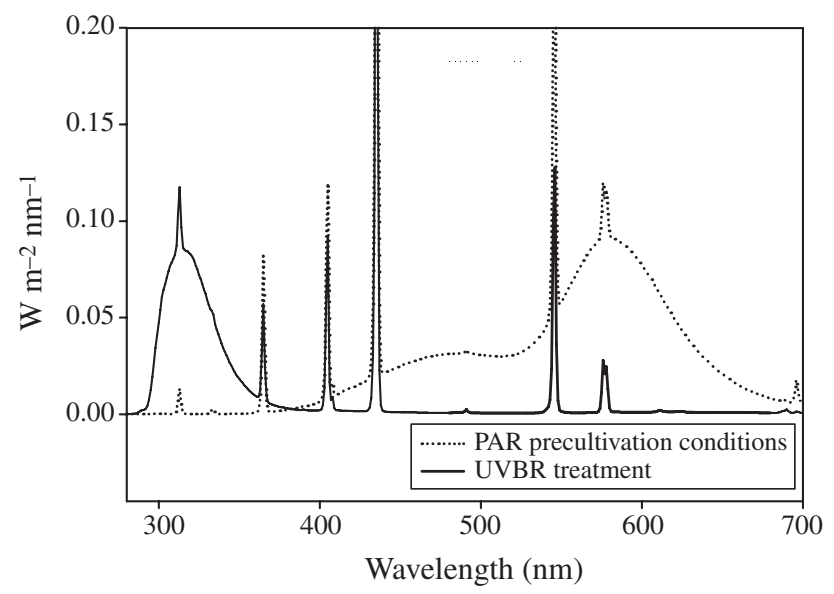

Fig. 1. Spectral irradiance conditions used for photosynthetically active radiation (PAR) acclimation (dotted curve) and the single ultraviolet-B radiation (UVBR) treatments (continuous curve). Spectra were corrected for spectral characteristics of the polystyrene flasks used in experiments. For irradiance levels, see 'Materials and methods'. Mean values of 2 replicates are presented

After acclimation, growth rates were measured over a $4 \mathrm{~d}$ period, and on Day 4, just prior to the UVBR treatment, samples were taken to measure pigments, UVRabsorbing compounds and MDA accumulation. Then, the flasks with the remaining culture suspensions were exposed to 1 single UVBR treatment for $2 \mathrm{~h}$ around noon (Philips TL 12, $0.1 \mathrm{~W} \mathrm{~m}^{-2}$, for spectral composition see Fig. 1) at a temperature of $1.0^{\circ} \mathrm{C}\left( \pm 0.5^{\circ} \mathrm{C}\right)$. The applied weighted dose (Minimal Erythemal Dose [MED] 3.6), roughly corresponds with a daily erythemal UVBR dose at approximately $4 \mathrm{~m}$ water depth at Davis Station (Antarctica) during a clear summer day, when assuming a UV attenuation constant in low-turbidity Antarctic marine coastal waters of 0.4 (Davidson \& van der Hiejden 2000). Cells were harvested for CPD analysis after exposure to UVBR. The entire experiment was repeated after several weeks, giving 2 independent replicates.

Analyses. For growth rate measurements, samples were taken on 4 consecutive days, fixed with Lugol's iodine $(0.1 \%$ final concentration $)$, diluted with filtersterilised seawater when necessary and settled in $5 \mathrm{ml}$ counting chambers; the entire chamber (1200 to 2500 cells) was screened using a Zeiss Axiovert inverted microscope under Nomarski optics at $100 \times$ or $400 \times$ magnification. Biovolumes of 200 cells of each species and acclimation irradiance were measured using stereometric formulas for flagellates and diatoms, as given by Hillebrand et al. (1999).

For pigment analyses with HPLC, between 50 and $80 \mathrm{ml}$ of culture was filtered onto Whatman GF/F filters under dim light and stored immediately in liquid nitrogen. To avoid de-epoxidation of xanthophyll cycle pigments, the time in between sampling, filtration and storage was typically $<2 \mathrm{~min}$. Samples were extracted in $3 \mathrm{ml}$ of $100 \% \mathrm{MeOH}$ under dim light, using apo-8'carotenal as internal standard. Pigments were analysed using the procedure described by Zapata et al. (2000). Pigments were detected using a Waters 996 photodiode array connected to Hitachi fluorescence detectors. Standards were isolated by semi-preparative HPLC, using procedures described by Repeta \& Bjørnland (1997), from well-characterised species including Amphidinium carterae, Dunaliella tertiolecta, Emiliania huxleyi, Micromonas pusilla, Pavlova lutheri and Pelagococcus subviridis, as recommended by Jeffrey \& Wright (1997).

For UVB-absorbing compounds, between 50 and $80 \mathrm{ml}$ of culture was filtered onto GF/F filters and stored at $-135^{\circ} \mathrm{C}$ until analysis, which was done within a few weeks. UV-absorbing compounds were measured spectrophotometrically following Tartarotti \& Sommaruga (2002), using $3 \mathrm{ml}$ of aqueous $25 \%$ methanol extraction at $45^{\circ} \mathrm{C}$ for $2 \mathrm{~h}$. Extracts were filtered through GF/F filters, and the absorption of the filtrate was recorded between 250 and $700 \mathrm{~nm}$ on a Hitachi spectrophotometer, revealing at least $1 \mathrm{UV}$ absorbance peak around $323 \mathrm{~nm}$. Baseline correction of all UV absorbance peaks was done using $25 \%$ $\mathrm{MeOH}$ as a blank, and further background correction (non-specific turbidity) was done by subtracting extrapolated background signals between 250 and $700 \mathrm{~nm}$, using Hitachi software. UV-absorbing compounds were expressed as absorption units per cell or biovolume.

MDA formation was assessed using the procedure of Heath \& Parker (1968). This spectrophotometric method measures total oxidated phospholipid content, with MDA as the major constituent. Therefore, the observed colorimetric response is generally referred to as TBAR (thiobarbituric acid reactive), rather than MDA. For TBAR measurements, between 70 and $100 \mathrm{ml}$ of culture (18 and $220 \mu \mathrm{mol} \mathrm{m} \mathrm{m}^{-2} \mathrm{~s}^{-1}$ PAR-acclimated cultures only) was filtered onto GF/F filters and stored at $-135^{\circ} \mathrm{C}$ until further analysis. Extraction was done for $30 \mathrm{~min}$ at $98^{\circ} \mathrm{C}$ in $3 \mathrm{ml}$ of solvent consisting of $1.5 \mathrm{ml} \mathrm{MilliQ}$ and $1.5 \mathrm{ml}$ of trichloroacetic acid (TCA, $20 \%$ in MilliQ) with thiobarbituric acid (TBA, 0.5\% [w/v], Sigma) and then put on ice immediately. After cooling, the extract was filtered to remove cell debris, after which absorption spectra between 450 and $600 \mathrm{~nm}$ were recorded on a Hitachi spectrophotometer. The extraction solvent (TCA-TBA/MilliQ, 50:50 [v/v]) was used as a blank. To correct for non-specific turbidity, average background absorption was measured over the whole range of the spectrum and subtracted from the TBAR peak at $532 \mathrm{~nm}$ using Hitachi software. MDA was calculated assuming a molar extinction coefficient of 155. 
For CPD analysis, 80 to $100 \mathrm{ml}$ of culture was harvested onto Osmonics polycarbonate membrane filters (47 $\mathrm{mm}, 0.2 \mu \mathrm{m}$ pore size) immediately after the UVBR treatment, and the filters were frozen at $-135^{\circ} \mathrm{C}$ until analysed. In short, DNA was extracted from the filters using the same procedure as described in Buma et al. (2001), which is a method modified from Doyle \& Doyle (1991). To remove RNA, the extracts were incubated for $1 \mathrm{~h}$ with $75 \mathrm{mg} \mathrm{ml}^{-1}$ RNase (Boehringer Mannheim) at room temperature. DNA concentrations of the extracts were determined fluorometrically using Picogreen dsDNA quantitation reagent (dilution 1:400, Molecular Probes) on a 1420 Victor multilabel counter (EG\&G Wallac, excitation $485 \mathrm{~nm}$, emission $535 \mathrm{~nm}$ ). The amount of CPDs was determined using the immuno-dotblot procedure described in Boelen et al. (2001), employing a primary antibody (H3, Affitech) directed mainly to thymine dimers. Each blot contained 2 dilution series of standard DNA with known amounts of CPDs. Significance of all results was tested using paired $t$-tests at $\mathrm{p}<0.05$.
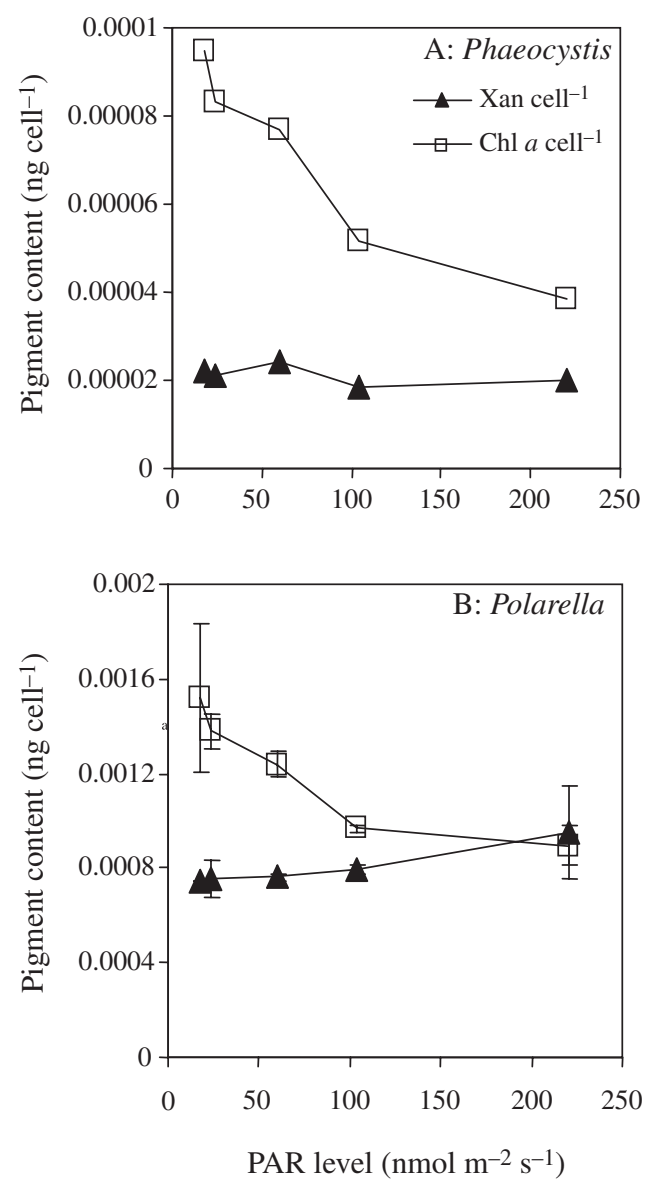

\section{RESULTS}

PAR acclimation affected the biovolumes of Polarella glacialis and Phaeocystis antarctica. For P. glacialis, the biovolume increased from $176 \pm 51.5 \mu^{3}$ at a PAR irradiance of $18 \mu \mathrm{mol} \mathrm{m} \mathrm{m}^{-2} \mathrm{~s}^{-1}$ to $535 \pm 350 \mu^{3}$ at $220 \mu \mathrm{mol} \mathrm{m}{ }^{-2} \mathrm{~s}^{-1}$ PAR. For P. antarctica flagellates, this was $13.1 \pm 4.7 \mu^{3}$ at $18 \mu \mathrm{mol} \mathrm{m} \mathrm{m}^{-2} \mathrm{~s}^{-1}$ and $19.8 \pm$ $11.8 \mu^{3}$ at $220 \mu \mathrm{mol} \mathrm{m}{ }^{-2} \mathrm{~s}^{-1}$, whereas the biovolumes of Chaetoceros dichaeta (mean biovolume of $2319 \pm$ $106 \mu^{3}$ ) and Pyramimonas gelidicola (202 $\pm 28 \mu^{3}$ ) were not affected by irradiance conditions. PAR acclimation strongly affected the pigment content and/or ratio in all species. In addition to chlorophyll a (chl a) and $\beta, \beta$-carotene, which occurred in all species, the significant pigments detected were: $C$. dichaetachl $C_{2}$, chl $C_{3}$, fucoxanthin, diadinoxanthin, diatoxanthin; $P$. antarctica- $\operatorname{chl~} C_{2}$, chl $C_{3}, 19^{\prime}$-butanoyloxyfucoxanthin, 19'-hexanoyloxyfucoxanthin, 4-keto-19'hexa-noyloxyfucoxanthin, diadinoxanthin, diatoxanthin; P. glacialis- $\operatorname{chl} C_{2}$, chl $c_{3}$, peridinin, diadinoxanthin,
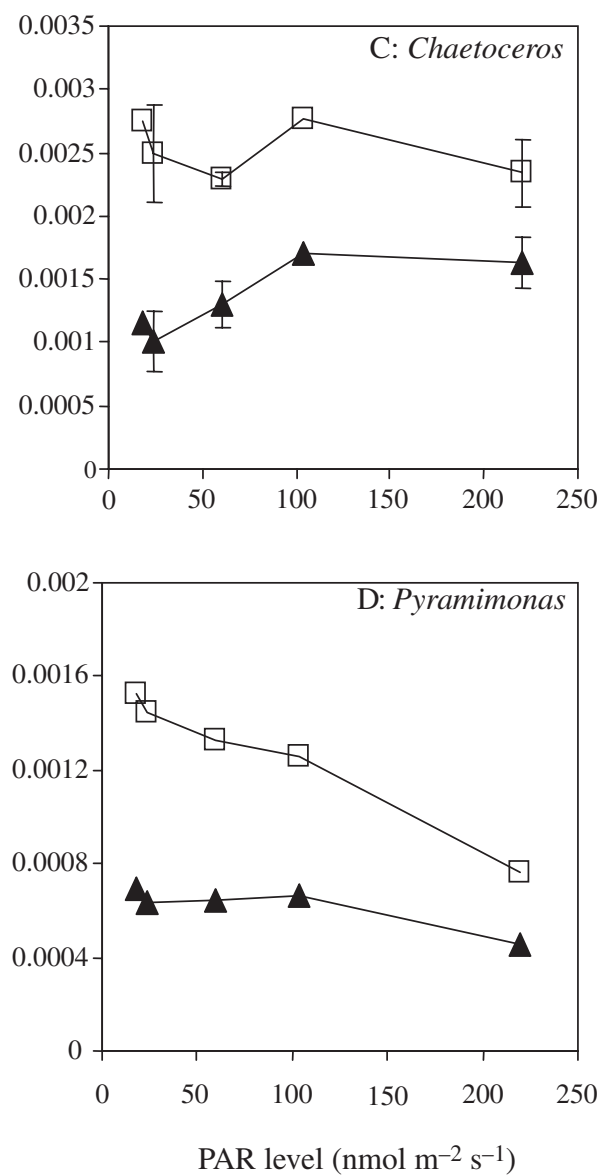

Fig. 2. Effects of PAR acclimation on pigment content in 4 Antarctic microalgae: (A) Phaeocystis antarctica, (B) Polarella glacialis, (C) Chaetoceros dichaeta and (D) Pyramimonas gelidicola ( $\mathbf{\Delta}$ : total xanthophyll [Xan] pigments cell ${ }^{-1}$; $\square$ : chlorophyll a [chl a] cell $^{-1}$; error bars: $\pm \mathrm{SE}$ ). Mean values of 2 replicate experiments are presented 
diatoxanthin, dinoxanthin; and $P$. gelidicola-chl $b$, neoxanthin, violaxanthin, antheraxanthin (minor), zeaxanthin (minor), lutein, $\beta, \varepsilon$-carotene. With the exception of $C$. dichaeta, cellular chl a content decreased sharply upon acclimation to the higher PAR intensities (Fig. 2). C. dichaeta and P. glacialis showed increased cellular contents of the xanthophyll cycle pigments (diadinoxanthin and diatoxanthin) between the lowest and highest PAR intensities, with concentrations rising from 0.00075 to $0.00095 \mathrm{ng}$ cell $^{-1}$ in P. glacialis and from 0.0011 to $0.0016 \mathrm{ng}$ cell $^{-1}$ in $C$. dichaeta (Fig. 2B,C). Acclimation to the highest irradiance level in $P$. glacialis resulted in a xanthophyll/chl a ratio $>1$ (Fig. 3B) due to a simultaneous decrease in chl a content and increase in cellular xanthophyll pigment concentrations. For the other 3 species, PAR acclimation caused a significant increase in this ratio as well; however, these changes were not as pronounced as for P. glacialis (Fig. 3). Xanthophyll cycle activity was measured as the EPS (Fig. 3), which significantly increased upon acclimation to higher PAR levels. EPS values were lowest for $P$. glacialis (Fig. 3B).

A clear PAR-related induction of UV-absorbing compounds was found for Phaeocystis antarctica and Polarella glacialis (Fig. 4A,B), while Chaetoceros dichaeta showed a maximum when cultivated at $100 \mu \mathrm{mol} \mathrm{m} \mathrm{m}^{-2} \mathrm{~s}^{-1}$ (Fig. 4C). No UV-absorbing compounds were found in Pyramimonas gelidicola (not shown). Normalisation of UV-absorbing compounds/ chl a content showed a significant increase for $P$. glacialis, increasing to 0.007 at the highest PAR level (Fig. 4B). P. antarctica also showed a clear increase;
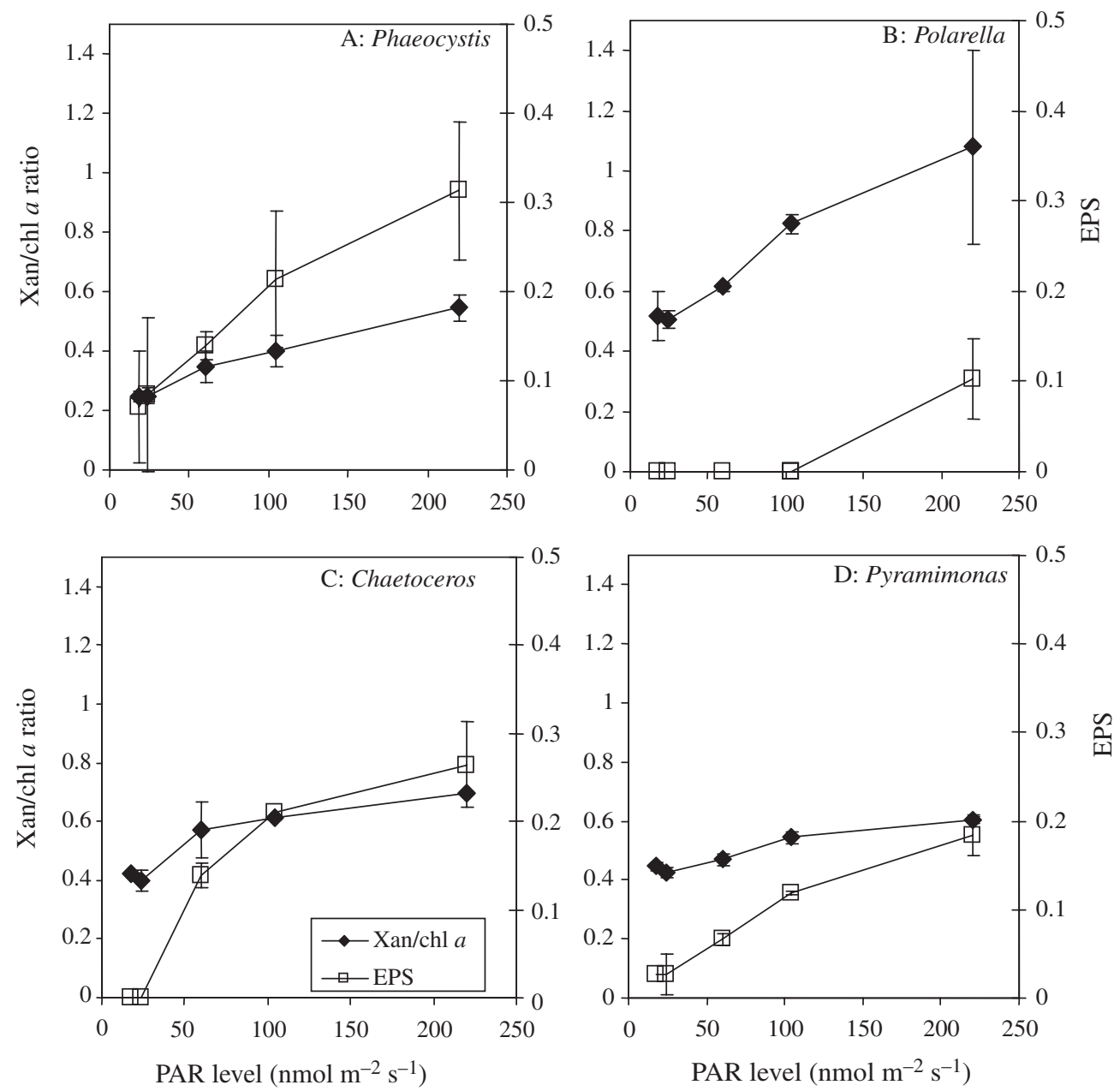

Fig. 3. Effects of PAR acclimation on xanthophyll pigments in 4 Antarctic microalgae: (A) Phaeocystis antarctica, (B) Polarella glacialis, (C) Chaetoceros dichaeta and (D) Pyramimonas gelidicola ( $\bullet$ ratio of total xanthophyll [Xan] pigments/chlorophyll a $[\mathrm{chl} \mathrm{a}$; $\square$ : epoxidation state [EPS: epoxidated xanthophyll pigment relative to total xanthophyll cycle pool, i.e. violaxanthin/ (violaxanthin + antheraxanthin + zeaxanthin) for Pyramimonas and diadinoxanthin/(diadinoxanthin + diatoxanthin) for other species tested]; error bars: $\pm \mathrm{SE}$ ). Mean values of 2 replicate experiments are presented 
however, the UV-absorbing compounds/chl a ratio remained much lower at the highest light intensity. Like the cell-specific UV-absorbing content, $C$. dichaeta had a maximum UV-absorbing compounds/chl a ratio at around $100 \mu \mathrm{mol} \mathrm{m} \mathrm{m}^{-2} \mathrm{~s}^{-1}$ (Fig. 4C). The strong UV absorption response of $P$. glacialis was further underlined when the UV-absorbing content was normalised to cell volume (Table 1).

With the exception of Chaetoceros dichaeta, which showed little change, cellular concentrations of MDA (expressed as TBARs) were higher in high-PARacclimated cultures than in those exposed to low PAR irradiances (Table 1). Concentrations of MDA in
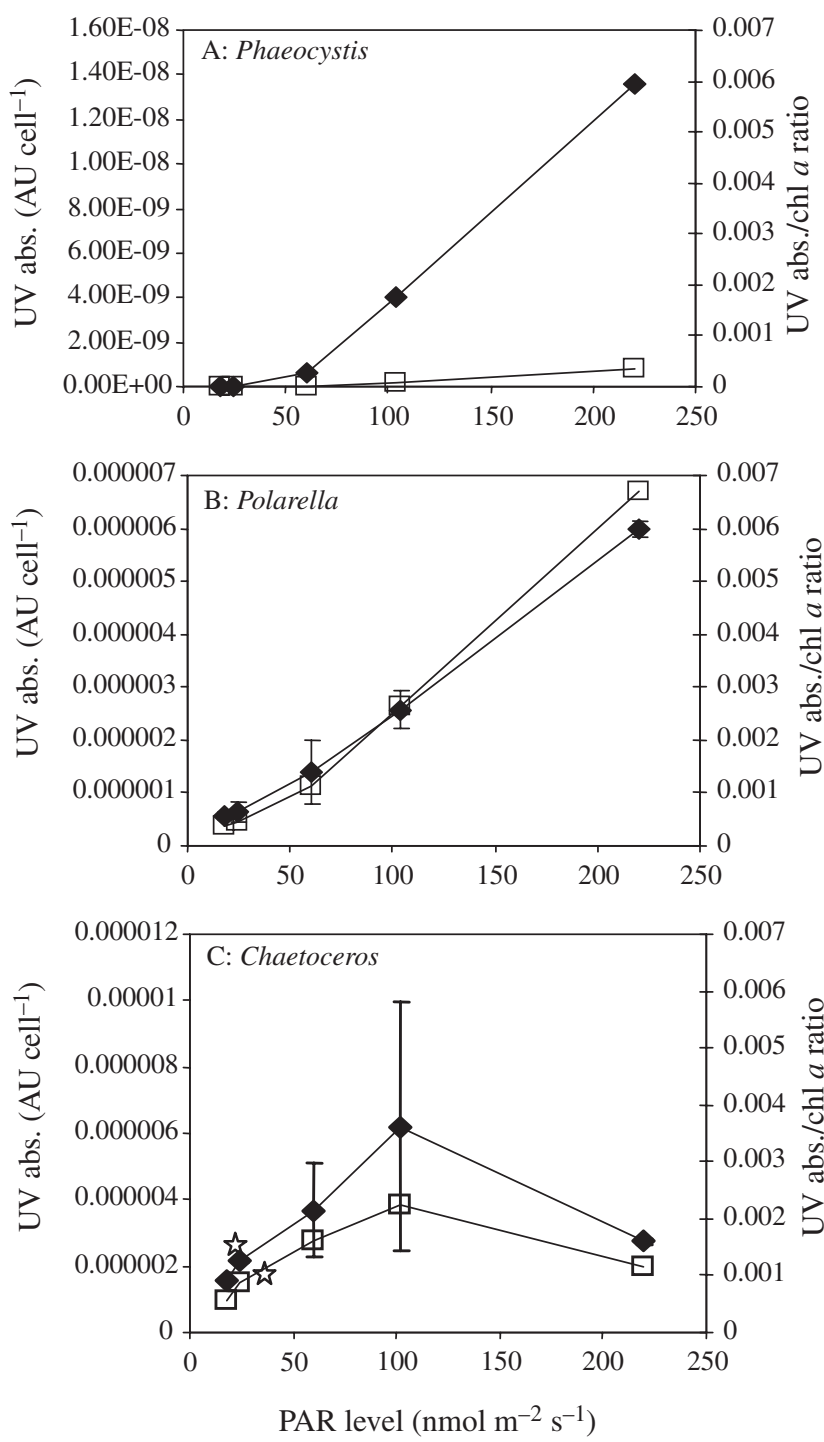

Fig. 4. Effect of PAR acclimation on UV-absorbing compounds (UV abs.): (A) Phaeocystis antarctica, (B) Polarella glacialis and (C) Chaetoceros dichaeta ( $\bullet$ UV abs. cell ${ }^{-1}$; $\square$ : UV abs./chl a ratio; error bars: \pm SE). Mean values of 2 replicate experiments are presented (AU: arbitrary units)
Table 1. Biovolume-specific contents of UV-absorbing compounds (UV abs.), malondialdehyde (MDA) and chlorophyll a (chl a) in Phaeocystis antarctica, Polarella glacialis, Chaetoceros dichaeta and Pyramimonas gelidicola under high and low PAR irradiance (HL: culture acclimated to high light [PAR irradiance $220 \mu \mathrm{mol} \mathrm{m} \mathrm{m}^{-2} \mathrm{~s}^{-1}$ ]; LL: culture acclimated to low light [PAR irradiance $18 \mu \mathrm{mol} \mathrm{m}{ }^{-2} \mathrm{~s}^{-1}$ ])

\begin{tabular}{|c|c|c|c|c|}
\hline Species & $\begin{array}{c}\text { PAR } \\
\text { condition }\end{array}$ & $\begin{array}{c}\text { UV abs. } \\
\text { (arbit. units) }\end{array}$ & 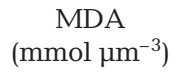 & $\begin{array}{c}\mathrm{Chl} a \\
\left(\mathrm{pg} \mu \mathrm{m}^{-3}\right)\end{array}$ \\
\hline C. dichaeta & HL & $1.19 \times 10^{-9}$ & $2.00 \times 10^{-11}$ & $1.01 \times 10^{-6}$ \\
\hline C. dichaeta & LL & $6.6 \times 10^{-10}$ & $1.19 \times 10^{-11}$ & $1.19 \times 10^{-6}$ \\
\hline P. gelidicola & a $\mathrm{HL}$ & 0 & $4.44 \times 10^{-13}$ & $3.76 \times 10^{-6}$ \\
\hline P. gelidicola & a LL & 0 & $5.99 \times 10^{-13}$ & $7.55 \times 10^{-6}$ \\
\hline P. glacialis & HL & $1.12 \times 10^{-8}$ & $1.94 \times 10^{-12}$ & $1.67 \times 10^{-6}$ \\
\hline P. glacialis & LL & $4.19 \times 10^{-10}$ & $8.87 \times 10^{-13}$ & $2.84 \times 10^{-6}$ \\
\hline P. antarctica & a HL & $6.88 \times 10^{-10}$ & $6.51 \times 10^{-10}$ & $1.95 \times 10^{-6}$ \\
\hline P. antarctica & a $\quad$ LL & 0 & $2.44 \times 10^{-10}$ & $4.79 \times 10^{-6}$ \\
\hline
\end{tabular}

Polarella glacialis, C. dichaeta and Phaeocystis antarctica were around 10, 30 and 100 times higher, respectively, than in P. gelidicola (Table 1).

Increased EPS and MDA formation did not reduce growth of any of the species at the highest PAR level $\left(220 \mu \mathrm{mol} \mathrm{m}{ }^{-2} \mathrm{~s}^{-1}\right)$. However, light limitation reduced growth of all species at the lowest PAR levels (Table 2). UVBR exposure for $2 \mathrm{~h}$ caused significant CPD induction in Pyramimonas gelidicola, whereas no CPD induction was found for the other species. In $P$. gelidicola, CPD accumulation was observed for all PAR acclimation levels, whereas CPD accumulation increased $>4$-fold at higher PAR acclimation levels (Fig. 5).

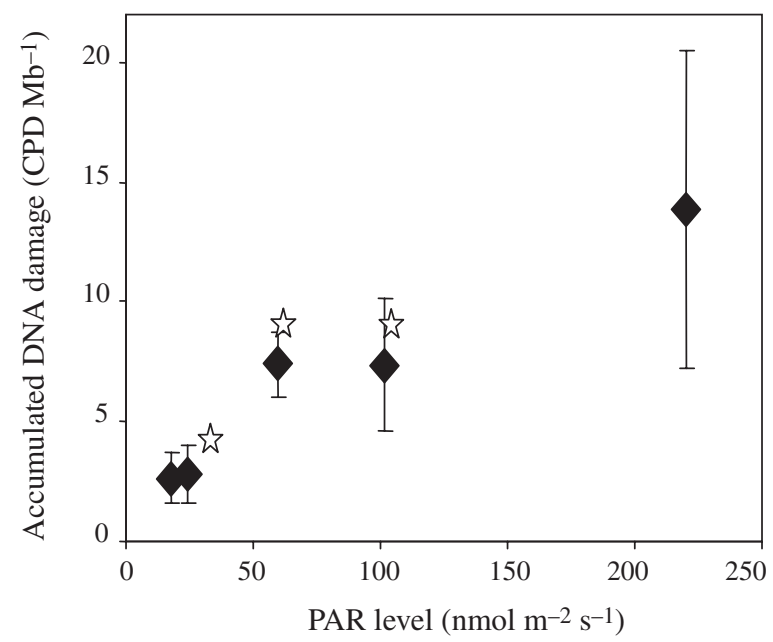

Fig. 5. Pyramimonas gelidicola. Effect of PAR acclimation on cyclobutane pyrimidine dimer (CPD per Mega base [Mb]) accumulation. Mean values of 2 replicates are presented (error bars: $\pm \mathrm{SE}$; stars: significant differences compared with the highest irradiance condition [t-test, $\mathrm{p}<0.05]$ ) 
Table 2. Specific growth rates $\left(\mathrm{d}^{-1}\right)$ of the 4 Antarctic microalgal species after PAR acclimation

\begin{tabular}{|ccccc|}
\hline $\begin{array}{l}\text { PAR level } \\
\left(\mu \mathrm{mol} \mathrm{m} \mathrm{m}^{-1}\right)\end{array}$ & $\begin{array}{c}\text { Chaetoceros } \\
\text { dichaeta }\end{array}$ & $\begin{array}{c}\text { Polarella } \\
\text { glacialis }\end{array}$ & $\begin{array}{c}\text { Pyramimonas } \\
\text { gelidicola }\end{array}$ & $\begin{array}{c}\text { Phaeocystis } \\
\text { antarctica }\end{array}$ \\
\hline 220 & $0.295 \pm 0.006$ & $0.229 \pm 0.031$ & 0.225 & $0.512 \pm 0.024$ \\
104 & $0.259 \pm 0.024$ & $0.161 \pm 0.030$ & 0.182 & $0.464 \pm 0.069$ \\
60 & $0.273 \pm 0.001$ & $0.225 \pm 0.068$ & 0.170 & $0.337 \pm 0.015$ \\
24 & $0.267 \pm 0.010$ & $0.132 \pm 0.040$ & 0.110 & $0.237 \pm 0.129$ \\
18 & $0.199 \pm 0.063$ & $0.111 \pm 0.114$ & 0.075 & $0.292 \pm 0.013$ \\
\hline
\end{tabular}

pigment content and by increasing both xanthophyll/chl a ratios as well as EPS. Increases in xanthophyll/chl a ratios are commonly observed in microalgae and higher plants subjected to high irradiance, including UVR (Paerl et al. 1983, Demers et al. 1991, Demmig-Adams \& Adams 1992, Buma et al. 2000). Polarella glacialis, in particular, was shown to be well equipped for high irradiance exposure, judging from its very high xanthophyll/chl a ratio, its low EPS value and very high content of UV-

\section{DISCUSSION}

The present study has shown inter- and intraspecific differences in vulnerability to accumulated UVB-induced DNA damage in Antarctic microalgae. Our experimental set-up excluding UVAR and PAR from the UVBR treatments was chosen because active photoregulation, photoprotection, as well as DNA repair during UVBR exposure had to be avoided. Therefore, results cannot be extrapolated to the field; the experiment was merely designed to collect fundamental information on PAR acclimation and subsequent $\mathrm{CPD}$ induction vulnerability in relation to pigmentation and UV absorption characteristics.

No CPD accumulation was found for Polarella glacialis, Chaetoceros dichaeta, or Phaeocystis antarctica at any PAR acclimation level, whereas CPDs accumulated in Pyramimonas gelidicola, with the highest CPD accumulation at the highest PAR acclimation levels. Seemingly in contrast, other studies we recently performed showed increased UVBR tolerance (PSII efficiency and viability) in high-PAR-acclimated diatoms (Poll et al. 2005). Lower UVBR vulnerability was also found, when cells had been acclimated to high PAR first, compared with low-light-acclimated cultures (Neale et al. 1998b, Litchman \& Neale 2005). In a natural Antarctic phytoplankton community, UVR effects were lower during noontime hours than during morning hours, suggesting that UVBR protection is induced during the course of the day (Figueroa et al. 1997). Other field observations revealed that low-lightacclimated Antarctic phytoplankton communities were more vulnerable to UVR photoinhibition than highlight-acclimated communities (Helbling et al. 1994, Neale et al. 1994, Villafane et al. 1995, Bracher \& Wiencke 2000). It is clear that discrepancies between observed UVBR effects, whether or not in relation with the biotic or abiotic environment, are primarily determined by the parameter under study (growth, viability, photosynthetic rate or efficiency, DNA damage) (Buma et al. 2003, Villafane et al. 2003).

In the current experiments, all species acclimated to increasing PAR by decreasing their light-harvesting absorbing compounds at the highest PAR acclimation levels. These characteristics clearly match the natural habitat of $P$. glacialis, since this species is found primarily in Antarctic sea ice, particularly in the brine of the upper fast ice (Montresor et al. 1999, Thomson et al. 2004). Here, irradiance conditions (including UVR) are consistently high in comparison with open, mixed waters or the under-ice environment. Furthermore, high UV absorbance is consistent with the observations made by Jeffrey et al. (1999) who demonstrated high structural MAA levels in a large number of dinoflagellate species. These and other observations (Vernet et al. 1989, Neale et al. 1998b) indicate that bloom-forming dinoflagellates and other microalgae are well equipped to grow at high natural irradiance levels, although a good correlation was not always found between MAA content and collection depth in dinoflagellates (Banaszak et al. 2000). In addition, the observed low intracellular MDA concentrations in $P$. glacialis further seem to indicate that intracellular metabolic activities or other antioxidant actions prevent rapid accumulation of harmful oxiradicals that could otherwise oxidise cellular membranes.

Except for Pyramimonas gelidicola, all species showed a clear induction of UVB-absorbing compounds with increasing irradiance of PAR acclimation, as described before for other Antarctic microalgae, such as Phaeocystis sp. (Riegger \& Robinson 1997, Moisan \& Mitchell 2001) or other prymnesiophytes and dinoflagellates (Carreto et al. 1990, Hannach \& Sigleo 1998). Earlier work (Marchant et al. 1991) had shown undetectable amounts of MAAs in Phaeocystis antarctica flagellates when cultivated under low PAR irradiance, which was confirmed in our experiments. Davidson \& Marchant (1992) and Peperzak et al. (2000) proposed that the flagellate stage in the life cycle of Phaeocystis spp. is an escape mechanism from the confines of colonial metabolism, the latter indicating that this life stage was initiated by low light. We found that photoacclimation of this alga to a range of PAR irradiances elicited the greatest percentage change in concentrations of intracellular UV absorbance and chl $a$ and the greatest growth rate range. Thus, $P$. antarctica flagellates had a high capacity to acclimate to changes in the light climate. If indicative of 
the photophysiology of Phaeocystis spp. flagellates in general, this plasticity may contribute to the reported persistence of this life stage throughout the year (Parke et al. 1971, Veldhuis et al. 1986, Verity et al. 1988) and the ubiquity of Phaeocystis spp. in temperate and polar waters (Davidson \& Marchant 1992).

Although a PAR-related difference was found in MDA levels for all species except Pyramimonas gelidicola (Table 1), we question whether these increases indicate substantial oxidative stress under our experimental conditions. Other marine studies showing enhanced MDA concentrations at excess irradiances were performed under (UV) irradiance levels much higher than ours (Malanga et al. 1997, Butow et al. 1998, Rijstenbil 2001, 2002, Bischof et al. 2003). Since oxidative stress is thought to be an imbalance between oxiradical action and antioxidative responses, it would be expected that growth rates at the highest irradiance level were affected. However, this was not observed (Table 2). The differences in MDA concentration may merely reflect differences in photosynthetic activity, thereby generating higher intracellular concentrations of radicals without causing chronic stress. In support of this, Phaeocystis antarctica growth was very rapid at the highest light intensities, while MDA concentrations were up to 2 magnitudes higher than the levels found in other species (Table 1). Therefore, the observed MDA levels might result from active cell metabolism, without impairment of photosynthesis or growth.

For some MAAs, antioxidant properties have been suggested in addition to their UV-absorbing function (Dunlap \& Yamamoto 1995). However, our analytical spectrophotometric procedure did not characterise the various UV-absorbing compounds. Pyramimonas gelidicola was the only species that accumulated CPDs, whereas, at the same time, it did not synthesise UVabsorbing compounds. It has to be stated that $P$. gelidicola might have induced UV-absorbing compounds under different spectral irradiance conditions (UVAR or a higher proportion of blue wavelengths). For this reason, $P$. gelidicola may show a different UVBR response under natural solar irradiance conditions. Our results with $P$. gelidicola could indicate a protective role of UV-absorbing compounds against CPD accumulation. On the other hand, no CPD accumulation was found in Phaeocystis antarctica cells that were acclimated to low PAR irradiance, which contained undetectable amounts of UV-absorbing compounds. Therefore, inter-specific vulnerability for UVBR-induced DNA damage may be due to other factors, such as structural differences in CPD repair capacity (Karentz et al. 1991, Poll et al. 2001) or other photoprotection mechanisms.

It has been postulated before (reviewed in Buma et al. 2003) that larger cells would be less vulnerable to
CPD induction than smaller cells, because of the differences in the intracellular light path (Karentz et al. 1991, Buma et al. 2001). However, the present study shows that other features must also be involved. We found CPD were not accumulated in the smallest species (Phaeocystis antarctica), but were accumulated in Pyramimonas gelidicola that had a 10 times larger biovolume (Fig. 5). Photorepair enzymes have been reported in marine red macroalgae inhabiting littoral areas exposed to high irradiance as opposed to sublittoral species. This hints at a strong habitat-related vulnerability to UVBR (Poll et al. 2001), as has also been suggested for microalgae (Davidson 2006). It is likely that organisms adapted to high mean irradiance habitats are well equipped to simultaneously overcome high PAR, UVAR and UVBR stress. For example, MAAs are found to be present in a range of microalgae, even when cultured under relatively low PAR levels (Jeffrey et al. 1999). This supports our observations of UV absorbance in Chaetoceros dichaeta and Polarella glacialis under PAR conditions as low as $18 \mu \mathrm{mol} \mathrm{m} \mathrm{m}^{-2} \mathrm{~s}^{-1}$. Contrasting with other species within the genus, $P$. gelidicola appeared less equipped for high irradiance environments, as xanthophyll cycle pigments decreased at the highest irradiances and other protective mechanisms such as UV-absorbing compounds were not induced.

Finally, intracellular chromophores can absorb UVBR photons, thereby reducing DNA damage via reduced intracellular UVBR transmission. The strong decline in cellular chl a content in high-PAR-acclimated Pyramimonas gelidicola, combined with a low photoprotection capacity (including the absence of UVabsorbing compounds), may therefore have contributed to enhanced CPD formation. Also, the higher growth rate at high PAR irradiances could have resulted in a higher proportion of DNA being unfolded for DNA replication (DNA synthesis phase). The complexity of photobiological responses in Antarctic microalgae needs to be further elucidated, especially given the observed shifts in the light climate in the Southern Ocean.

Acknowledgements. This work was funded by NWO/MEERVOUD Grant Number 836.01.040 (A.G.J.B.) and NWO/NAAP Grant Number 851.20.015 (W.H.v.d.P.). Australian components of the work were supported by the Australian government's Cooperative Research Centres Programme through the Antarctic Climate and Ecosystems Cooperative Research Centre (ACE CRC) and the Australian Antarctic Science program (Projects 40, S.W.W., and 2210, A.T.D.).

\section{LITERATURE CITED}

Banaszak AT (2003) Photoprotective physiological and biochemical responses of aquatic organisms. In: Helbling EW, Zagarese $\mathrm{H}$ (eds) UV effects in aquatic organisms and ecosystems. Comprehensive series in photochemistry and 
photobiology, Vol 1. Royal Society of Chemistry, Cambridge, p 329-357

Banaszak AT, LaJeunesse T, Trench RK (2000) The synthesis of mycosporine-like amino-acids (MAAs) by cultured symbiotic dinoflagellates. J Exp Mar Biol Ecol 249: 219-233

Behrenfeld MJ, Lee II H, Small LF (1994) Interactions between nutritional status and long-term responses to UV$\mathrm{B}$ radiation stress in a marine diatom. Mar Biol 118: 523-530

Bischof K, Janknegt PJ, Buma AGJ, Rijstenbil JW, Peralta G, Breeman AM (2003) Oxidative stress and enzymatic scavenging of superoxide radicals induced by solar UV-B radiation in Ulva canopies from southern Spain. Sci Mar 67: 353-359

Boelen P, Veldhuis MJW, Buma AGJ (2001) Accumulation and removal of UVBR-induced DNA damage in marine tropical plankton subjected to mixed and simulated nonmixed condition. Aquat Microb Ecol 24:265-274

Bothwell ML, Sherbot D, Roberge AC, Daley RJ (1993) Influence of natural ultraviolet radiation on lotic periphytic diatom community growth, biomass accrual and species composition, short-term versus long-term effects. J Phycol 29:24-35

Bracher AU, Wiencke C (2000) Simulation of the effects of naturally enhanced UV radiation on photosynthesis of Antarctic phytoplankton. Mar Ecol Prog Ser 196:127-141

Buma AGJ, van Oyen T, van de Poll WH, Veldhuis MJW, Gieskes WWC (2000) The sensitivity of the marine prymnesiophyte Emiliania huxleyi to ultraviolet-B radiation. J Phycol 36:296-303

Buma AGJ, de Boer MK, Boelen P (2001) Depth distributions of DNA damage in Antarctic marine phyto- and bacterioplankton exposed to summertime ultraviolet radiation. J Phycol 37:200-208

Buma AGJ, Boelen P, Jeffrey WH (2003) UVR-induced DNA damage in aquatic organisms. In: Helbling EW, Zagarese $\mathrm{H}$ (eds) UV effects in aquatic organisms and ecosystems. Comprehensive series in photochemistry and photobiology, Vol 1. Royal Society of Chemistry, Cambridge, p 291-329

Butow BJ, Wynne D, Sukenik A, Hadas O, Tel-Or E (1998) The synergistic effect of carbon concentration and high temperature on lipid peroxidation in Peridinium gatunense. J Plankton Res 20:355-369

Carreto JJ, Carignan MO, Daleo G, de Marco SG (1990) Occurrence of mycosporine-like amino acids in the redtide dinoflagellate Alexandrium excavatum: UV-photoprotective compounds? J Plankton Res 12:909-921

Davidson AT (2006) Effects of ultraviolet radiation on microalgal growth, survival and production. In: Rao SDV (ed) Algal cultures, analogues of blooms and applications. Science Publishers, Gainsville, FL

Davidson AT, Belbin L (2002) Exposure of natural Antarctic marine microbial assemblages to ambient UV radiation: effects on the marine microbial community. Aquat Microb Ecol 27:159-174

Davidson AT, Marchant HJ (1992) The biology and ecology of Phaeocystis (Prymnesiophyceae). In: Round FE, Chapman DJ (eds) Progress in phycological research, Vol 8. Biopress, Bristol, p 1-46

Davidson AT, van der Hiejden A (2000) Exposure of natural Antarctic marine microbial assemblages to ambient UV radiation: effects on bacterioplankton. Aquat Microb Ecol 21:257-264

Davidson AT, Bramich D, Marchant HJ, McMinn A (1994) Effects of UV-B irradiation on growth and survival of Antarctic marine diatoms. Mar Biol 119:507-515
Demers S, Roy S, Gagnon R, Vignault C (1991) Rapid light induced changes in cell fluorescence and in xanthophyllcycle pigments of Alexandrium excavatum (Dinophyceae) and Thalassiosira pseudonana (Bacillariophyceae): a photoprotection mechanism. Mar Ecol Prog Ser 76:185-193

Demmig-Adams B, Adams WW (1992) Photoprotection and other responses of plants to high light stress. Annu Rev Plant Physiol Plant Mol Biol 43:599-626

Doyle JJ, Doyle JL (1991) Isolation of plant DNA from fresh tissue. Focus 12:13-15

Dunlap WC, Yamamoto Y (1995) Small-molecule antioxidants in marine organisms: antioxidant activity of mycosporineglycine. Comp Biochem Physiol B 112:105-114

Figueroa FL, Blanco JM, Jimenez-Gomez F, Rodriguez J (1997) Effects of ultraviolet radiation on carbon fixation in Antarctic nanophytoflagellates. Photochem Photobiol 66:185-189

Hannach G, Sigleo AC (1998) Photoinduction of UV-absorbing compounds in six species of marine phytoplankton. Mar Ecol Prog Ser 174:207-222

Heath RL, Parker L (1968) Photoperoxidation in isolated chloroplasts. I. Kinetics and stoichiometry of fatty acid peroxidation. Arch Biochem Biophys 125:189-198

Helbling EW, Villafane VE, Holm-Hansen O (1994) Effects of ultraviolet radiation on Antarctic marine phytoplankton photosynthesis with particular attention to the influence of mixing. In: Weiler CS, Penhale PA (eds) Ultraviolet radiation in Antarctica: measurements and biological effects. Antarctic research series, Vol 62. American Geophysical Union, Washington, DC, p 207-227

Hillebrand H, Duerselen C-D, Kirschtel D, Pollingher U, Zohary T (1999) Biovolume calculation for pelagic and benthic microalgae. J Phycol 35:403-424

Holm-Hansen O, Helbling EW, Lubin D (1993) Ultraviolet radiation in Antarctica: inhibition of primary production. Photochem Photobiol 58:567-570

Jeffrey SW, Wright SW (1997) Qualitative and quantitative HPLC analysis of SCOR reference algal standards. In: Jeffrey SW, Mantoura RFC, Wright SW (eds) Phytoplankton pigments in oceanography: guidelines to modern methods. UNESCO, Paris, p 343-360

Jeffrey SW, MacTavish HS, Dunlap WC, Vesk M, Groenewoud K (1999) Occurrence of UVA- and UVB-absorbing compounds in 152 species (206 strains) of marine microalgae. Mar Ecol Prog Ser 189:35-51

Karentz D, Cleaver JE, Mitchell DL (1991) Cell survival characteristics and molecular responses of Antarctic phytoplankton to ultraviolet-B radiation. J Phycol 27:326-341

Lesser MP, Cullen JJ, Neale PJ (1994) Carbon uptake in a marine diatom during acute exposure to ultraviolet-B radiation: relative importance of damage and repair. J Phycol 30:183-192

Litchman E, Neale PJ (2005) UV effects on photosynthesis, growth and acclimation of an estuarine diatom and cryptomonad. Mar Ecol Prog Ser 300:53-62

Litchman E, Neale PJ, Banaszak AT (2002) Increased sensitivity to ultraviolet radiation in nitrogen-limited dinoflagellates. Limnol Oceanogr 47:86-94

Loeblich AR (1975) A seawater medium for dinoflagellates and the nutrition of Cachonina niei. J Phycol 11:80-86

Loeblich AR, Smith VE (1968) Chloroplast pigments of the marine dinoflagellate Gymnodinium resplendens. Lipids 3:3-15

Malanga G, Calmanovici G, Puntarulo S (1997) Oxidative damage to chloroplasts from Chlorella vulgaris exposed to ultraviolet-B radiation. Physiol Plant 101:455-462

Marchant HJ, Davidson AT, Kelly GJ (1991) UV-B protecting compounds in the marine alga Phaeocystis pouchetii from Antarctica. Mar Biol 109:391-395 
Moisan TA, Mitchell BG (2001) UV absorption by mycosporine-like amino acids in Phaeocystis antaractica Karsten induced by photosynthetically available radiation. Mar Biol 138:217-227

Montresor M, Procaccini G, Stoecker DK (1999) Polarella glacialis, gen. nov., sp. nov. (Dinophyceae): Suesiaceae are still alive! J Phycol 35:186-197

Mostajir JB, Demers S, de Mora SJ, Belzile C and 6 others (1999) Experimental test of the effect of ultraviolet-B radiation in a planktonic community. Limnol Oceanogr 44: 586-596

Mousseau L, Gosselin M, Levasseur M, Demers S, Fauchot J, Roy S, Villegas PZ, Mostajir B (2000) Effects of ultraviolet$\mathrm{B}$ radiation on simultaneous carbon and nitrogen transport rates by estuarine phytoplankton during a week-long mesocosm study. Mar Ecol Prog Ser 199:69-81

Neale PJ, Lesser MP, Cullen JJ (1994) Effects of ultraviolet radiation on the photosynthesis of phytoplankton in the vicinity of McMurdo Station ( $\left.78^{\circ} \mathrm{S}\right)$. In: Weiler CS, Penhale PA (eds) Ultraviolet radiation in Antarctica: measurements and biological effects. Antarctic research series, Vol 62 . American Geophysical Union, Washington, DC, p 125-142

Neale PJ, Davis RF, Cullen JJ (1998a) Interactive effects of ozone depletion and vertical mixing on photosynthesis of Antarctic phytoplankton. Nature 392:585-589

Neale PJ, Banaszak AT, Jarriel CR (1998b) Ultraviolet sunscreens in Gymnodinium sanguineaum (Dinophyceae): mycosporine-like amino acids protect against inhibition of photosynthesis. J Phycol 34:928-938

Neale PJ, Helbling EW, Zagarese HE (2003) Modulation of UVR exposure and effects by vertical mixing and advection. In: Helbling EW, Zagarese $\mathrm{H}$ (eds) UV effects in aquatic organisms and ecosystems. Comprehensive series in photochemistry and photobiology, Vol 1. Royal Society of Chemistry, Cambridge, p 107-137

Olaizola M, LaRoche J, Kolber Z, Falkowski PG (1994) Nonphotochemical fluorescence quenching and the diadinoxanthin cycle in a marine diatom. Photosynth Res 41: $357-370$

Paerl HW, Tucker J, Bland PT (1983) Carotenoid enhancement and its role in maintaining blue-green (Microcystis aeruginosa) surface blooms. Limnol Oceanogr 28:847-857

Parke M, Green JC, Manton I (1971) Observations of the fine structure of zooids of the genus Phaeocystis (Haptophyceae). J Mar Biol Assoc UK 51:927-941

Peperzak L, Colijn F, Vrieling EG, Gieskes WWC, Peeters $\mathrm{JCH}$ (2000) Observations of flagellates in colonies of Phaeocystis globosa (Prymnesiophyceae): a hypothesis for their position in the life cycle. J Plankton Res 22: 2181-2203

Poll van de WH, Eggert A, Buma AGJ, Breeman AM (2001) Effects of UV-B induced DNA damage and photoinhibition on growth of temperate marine red macrophytes: habitat-related differences in UV-B tolerance. J Phycol 37: $30-37$

Poll van de WH, van Leeuwe MA, Roggeveld J, Buma AGJ (2005) Nutrient limitation and high irradiance acclimation reduce PAR and UV induced viability loss in the Antarctic diatom Chaetoceros brevis. J Phycol 41:840

Quesada A, Mouget JL, Vincent WF (1995) Growth of Antarctic cyanobacteria under ultraviolet radiation: UVA counteracts UVB inhibition. J Phycol 31:242-248

Repeta DJ, Bjørnland T (1997) Preparation of carotenoid standards. In: Jeffrey SW, Mantoura RFC, Wright SW (eds) Phytoplankton pigments in oceanography: guidelines to modern methods. UNESCO, Paris, p 239-260
Riegger L, Robinson D (1997) Photoinduction of UV-absorbing compounds in Antarctic diatoms and Phaeocystis antarctica. Mar Ecol Prog Ser 160:13-25

Rijstenbil JW (2001) Effects of periodic, low UVA radiation on cell characteristics and oxidative stress in the marine planktonic diatom Ditylum brightwellii. Eur J Phycol 36: $1-8$

Rijstenbil JW (2002) Assessment of oxidative stress in the planktonic diatom Thalassiosira pseudonana in response to UVA and UVB radiation. J Plankton Res 24(12): $1277-1288$

Shelley K, Heraud P, Beardall J (2002) Nitrogen limitation in Dunaliella tertiolecta (Chlorophyceae) leads to increased susceptability to damage by ultraviolet-B radiation but also increased repair capacity. J Phycol 38:713-720

Smith RC, Prezelin BB, Baker KS, Bidigare RR and 9 others (1992) Ozone depletion: ultraviolet radiation and phytoplankton biology in Antarctic waters. Science 255: 952-959

Takahashi S, Nakajima N, Saji H, Kondo N (2002) Diurnal change in cucumber CPD photolyase gene (CsPHR) expression and its physiological role in growth under UV-B irradiation. Plant Cell Physiol 43:342-349

Tartarotti B, Sommaruga R (2002) The effect of different methanol concentrations and temperatures on the extraction of mycosporine-like amino acids (MAAs) in algae and zooplankton. Arch Hydrobiol 154:691-703

Thomson PG, Wright SW, Bolch CJS, Nichols PD, Skerratt JH, McMinn A (2004) Antarctic distribution, pigment and lipid composition, and molecular identification of the brine dinoflagellate Polarella glacialis (Dinophyceae). J Phycol 40:867-873

Veldhuis MJW, Colijn F, Venekamp LAH (1986) The spring bloom of Phaeocystis pouchetii (Haptophyceae) in Dutch coastal waters. Neth J Sea Res 20:37-48

Verity PG, Villareal T, Smayda TJ (1988) Ecological investigations of blooms of colonial Phaeocystis pouchetii. II. The role of life cycle phenomena in bloom termination. J Plankton Res 10:749-766

Vernet M (2000) Effects of ultraviolet radiation on the physiology and ecology of marine phytoplankton. In: de Mora S, Demers S, Vernet M (eds) The effects of UV radiation in the marine environment. Cambridge University Press, Cambridge, p 237-278

Vernet M, Neori A, Haxo FT (1989) Spectral properties and photosynthetic action in red-tide populations of Prorocentrum micans and Gonyaulax polyedra. Mar Biol 103:365-371

Villafane VE, Helbling EW, Holm-Hansen O, Chalker BE (1995) Acclimatization of Antarctic natural phytoplankton assemblages when exposed to solar ultraviolet radiation. J Plankton Res 17:2295-2306

Villafane VE, Sundback K, Figueroa FL, Helbling EW (2003) Photosynthesis in the aquatic environment as affected by UVR. In: Helbling EW, Zagarese H (eds) UV effects in aquatic organisms and ecosystems. Comprehensive series in photochemistry and photobiology, Vol 1. Royal Society of Chemistry, Cambridge, p 357-399

Waterworth WM, Jiang Q, West CE, Nikaido M, Bray CM (2002) Characterization of Arabidopsis photolyase enzymes and analysis of their role in protection from ultraviolet-B radiation. J Exp Bot 53:1005-1015

Zapata M, Rodriguez F, Garrido JL (2000) Separation of chlorophylls and carotenoids from marine phytoplankton:a new method using reversed-phase C8 column and pyridine-containing mobile phases. Mar Ecol Prog Ser 195:29-45

Submitted: July 13, 2005; Accepted: November 10, 2005

Proofs received from author(s): May 17, 2006 